\title{
Variation in Direct Solar Irradiation with Relative Humidity and Atmospheric Temperature
}

\author{
Aref Wazwaz ${ }^{1 *}$, Mohd Shariq Khan ${ }^{1}$ \\ ${ }^{1}$ Chemical Engineering Department, College of Engineering, Dhofar University, P.O. Box 2509, 211 Salalah, \\ Oman \\ * Corresponding author's e-mail: aref@du.edu.om
}

\begin{abstract}
A class first Pyranometer was used to measure the direct solar irradiation and the obtained results were analyzed. Separate sensors were used to measure the relative humidity and the atmospheric temperature (RH/AT sensors). The measurements were conducted for the whole year of 2013. The author analyzed the collected solar data during one day, month, and year. The maximum, minimum, average, and accumulative solar irradiation (SR) were calculated and analyzed with connection to relative humidity and atmospheric temperature. The author found that April was characterized by the average maximum solar irradiation $\left(\mathrm{SR}=1112 \pm 1 \mathrm{~W} / \mathrm{m}^{2}\right)$, May had the maximum SR accumulation $\left(13276552 \pm 1 \mathrm{~W} / \mathrm{m}^{2}\right)$. The maximum average percentage relative humidity found in July $(\% \mathrm{RH}=97 \pm 3 \%)$, while the minimum average $\% \mathrm{RH}$ is in December $(\% \mathrm{RH}=25 \pm 3 \%)$. In May, the maximum average atmospheric temperature was $36.0 \pm 0.6^{\circ} \mathrm{C}$, while the average minimum was in January $\left(\mathrm{AT}=19.1 \pm 0.6^{\circ} \mathrm{C}\right)$. The total accumulation of solar flux during the year 2013 is $222 \pm 1 \mathrm{MW} / \mathrm{m}^{2}$.
\end{abstract}

Keywords: solar irradiation, pyranometer, relative humidity, atmospheric temperature, accumulative solar flux

\section{INTRODUCTION}

Solar energy is one of the most essential resources of renewable energy. It is clean, safe, and non- pollutant for the environment. One hour of the solar energy reaching the surface of the Earth is equivalent to all needs of energy for all humans on the Earth for one year. The solar energy data is vital for conducting the feasibility studies for solar energy systems. The solar data is essential in many applications like designing PV systems, solar collectors, solar dryers, and in buildings [Ertekin \& Yaldiz, 1999] [Sabziparver \& Shetaee, 2007]. The solar data values of direct normal irradiance allow one to derive precise information on the performance of solar energy systems [Lopez, Rubio \& Batlles, 2000]. There are different techniques and devices used to measure the solar radiation. The received solar energy depends on the time during a day and during the season. In addition, it depends on the geographical place [Scharmer \& Greif, 2000]. For a country like Oman, the economical and efficient application of solar energy is dependent on the solar data. Different types of devices are used to measure the solar flux, like pyrheliometer, Pyranometer [Paulescu, et al., 2012]. The collected solar data is very important for researchers or any person working in the solar field. There are many scientists who used different models to predict solar flux.

Several scientists measured the solar irradiation as a reference [Lee, Yoo, \& Levermore, 2013] measured the global solar irradiation on a horizontal surface for major cities of South Korea during the period (1986-2005). In North Mexico City, Matsumoto [Matsumoto et al., 2014] measured the global-horizontal solar radiation from 1999 until 2012 [Perez, Bilbao \& De-Meguel., 2014] measured the monthly mean hourly values of direct irradiance for different locations in Spain characterized by different climatic conditions. The study carried out during the period (2002-2012) [Gairaa \& Benkaciali, 2011] performed hourly measurements of global and diffuse radiant fluxes 
at Ghardaia in southern Algerian peninsula from January 1, 2005, to December 31, 2008. The collected data are very important in the design of building energy systems. In Saudi Arabia, they made Solar Atlas in February 2014, which provides live data recorded from 41 stations across the country [AlYahya \& Irfan, 2016].

In our study, solar irradiation was measured for the first time at Dhofar University (North AlSaadah-Salalah) to have a data bank for utilizing solar energy for different purposes. Al-SaadahSalalah is at $17.0167^{\circ} \mathrm{N}$, and $54.0929^{\circ} \mathrm{E}$. This study was carried out in the period from January 1, 2012, until December 31, 2013 [Wazwaz \& Salmi, 2010]. The Automated Weather Station (AWS) was constructed at the roof of the Chemical Engineering Department. The AWS composed of the first-class Pyranometer, along with the RH/ Temperature sensors. There are different models used to calculate the solar irradiance (direct and diffuse) by connecting it with humidity and ambient temperature [Jimenez, Barrionuevo \& Rodriguez, 2016] [Loutfi et al., 2017].

\section{EXPERIMENTAL}

\section{Installation of the Automated Weather Station (AWS)}

We installed the Automated Weather Station (AWS) on the roof of the Chemical Engineering Department - College of Engineering- Dhofar University- North of AlSaadah-Salalah Oman. The station consisted of a pyranometer (first class), and relative humidity/atmospheric temperature (RH/AT) sensors. The specifications of the Pyranometer and the RH/AT illustrated in Table 1 and 2, respectively. The AWS was bought from Coastal Environmental Systems, Inc.

The utilized pyranometer used is first class (S80124, coastal Environmental Systems). This solar radiation sensor is applied in scientific grade solar radiation observations. It complies with the "first class" specifications within the latest ISO and WMO standards. It serves to measure the solar radiation flux that is incident on a plane surface in $\mathrm{W} / \mathrm{m}^{2}$ from a 180 degrees field of view (also called "global" solar radiation). Working completely passive, using a thermopile sensor, the sensor generates a small output voltage proportional to this flux. Employing two glass domes, certain measurement errors are reduced; in
Table 1: Specifications of pyranometer

\begin{tabular}{|l|l|}
\hline \multicolumn{1}{|c|}{ Item } & \multicolumn{1}{c|}{ Specification } \\
\hline ISO classification & First Class \\
\hline Spectral range & 305 to $2800 \mathrm{~nm}$ \\
\hline Sensitivity (nominal) & $15 \mu \mathrm{V} / \mathrm{Wm}^{-2}$ \\
\hline Temperature range & -40 to $+80^{\circ} \mathrm{C}$ \\
\hline Range & 0 to $2000 \mathrm{Wm}^{-2}$ \\
\hline Temperature dependence & $<0.1 \%{ }^{\circ} \mathrm{C}$ \\
\hline Calibration traceability & WRR \\
\hline
\end{tabular}

particular, thermal offsets, so that high measurement accuracy can be attained. The sensor can be directly connected to most commonly used data logging systems. It used for scientific meteorological observations, building physics, climateand solar collector testing. A common application is for outdoor solar radiation measurements as part of a meteorological station. This application requires horizontal leveling; leveling feet and a level are included. The cable can be installed or replaced by the user. The applicable standards are ISO 9060 and 9847, WMO (World Meteorological Organization), and ASTM E824-94. It used for stability estimations according to EPA.

The relative humidity and air temperature sensor (RH/AT sensors) is compact and easy to use. The relative humidity element is a hygroscopic capacitive type. It is interchangeable. These elements never need calibration. Instead, the elements are easily replaced without the expense and inconvenience sometimes associated with the calibration process. The membrane filter/ mechanical housing of the sensor protects it from dust and dirt.

The AWS connected to a PC and controlled by software (INTERCEPT V1.17.62). The AWS is working day and night, continuously recording the readings every minute. The collected data are

Table 2: Specifications of RH/AT sensors.

\begin{tabular}{|l|l|}
\hline \multicolumn{1}{|c|}{ Item } & \multicolumn{1}{c|}{ Specification } \\
\hline RH Accuracy & $+/-3 \%$ \\
\hline RH Resolution & $0.1 \%$ \\
\hline RH Range & $0-100 \% \mathrm{RH}$ \\
\hline $\begin{array}{l}\text { Operational Temperature } \\
\text { Range }\end{array}$ & $-30^{\circ} \mathrm{C}$ to $+60^{\circ} \mathrm{C}$ \\
\hline Storage Temperature & $-80^{\circ} \mathrm{C}$ to $+80^{\circ} \mathrm{C}$ \\
\hline AT Accuracy & $+/-0.6^{\circ} \mathrm{C}$ \\
\hline Time Constant, Max & $\begin{array}{l}1 \mathrm{sec} \text { in well-stirred oil. } 15 \\
\text { sec in still air }\end{array}$ \\
\hline Shield & $\begin{array}{l}\text { Gill multi-plate naturally } \\
\text { ventilated shield }\end{array}$ \\
\hline Typical Error In Full Sunlight & $0.5^{\circ} \mathrm{C}$ \\
\hline
\end{tabular}




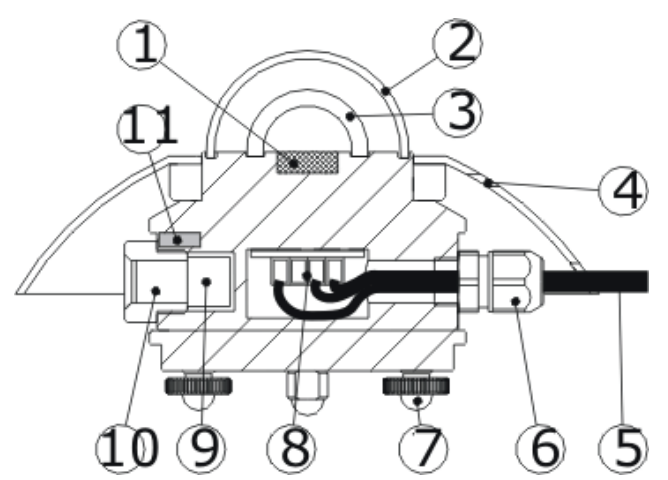

Figure 1: Solar radiation sensor

processed, analyzed and plotted. Figure 1 shows all parts of the first class Pyranometer and RH/ AT sensors, respectively. The numbers inscribed in Figure 1 are describes as follows:

1. Detector

2. Outer glass dome.

3. Inner glass dome.

4. Sun shield.

5. Cable.

6. Connector.

7. Adjustable feet.

8. Smart interface.

9. Humidity indicator.

10. Desiccant.

11. Bubble level.

Figure 2 shows the installed automated weather station installed on the roof of the Chemical Engineering Department at Dhofar University.

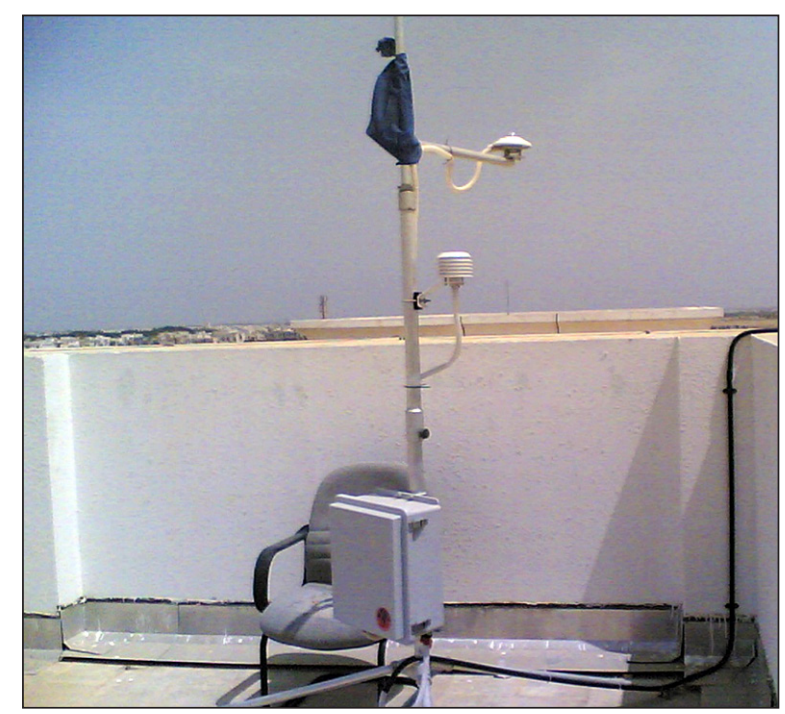

Figure 2: Automated weather station on the roof of the Chemical Engineering Department at Dhofar University

\section{RESULTS AND DISCUSSION}

\section{Calculations during the day}

The Automated Weather Station (AWS) collects the solar data, Relative Humidity (RH) and Atmospheric Temperature (AT) during the day per minute and sends it via the data logger to be saved on the PC. The collected data was analyzed using Excel. Figure 3 below shows the data collected during the first day of January 2013 where SR represents the solar flux (solar irradiation).

The time of measurement started at 12:00 AM mid night until 11:59 PM next day (working 24 hours).

Figure 3 indicated the following parameters during that day: 1 . SR: Maximum of $\mathrm{SR}=846$ $\pm 1 \mathrm{~W} / \mathrm{m}^{2}$, Average of SR $=506 \pm 1 \mathrm{~W} / \mathrm{m}^{2}$, Accumulative of $\mathrm{SR}=338718 \pm 1 \mathrm{~W} / \mathrm{m}^{2}$. 2 . RH: Maximum of $\mathrm{RH}=42 \pm 3 \%$, Average of $\mathrm{RH}=29$ $\pm 3 \%$, Minimum of RH $=16 \pm 3 \%$. 3. AT: Maximum of AT $=28.4 \pm 0.6^{\circ} \mathrm{C}$, Average of $\mathrm{AT}=22.5$ $\pm 0.6^{\circ} \mathrm{C}$, Minimum of AT $=17.8 \pm 0.6^{\circ} \mathrm{C}$. We did the same calculations for all days of all months of the year 2013 .

\section{Calculations during the month}

During each month of the year 2013, the author performed the calculations to find the Maximum of SR, Average of SR, Accumulative of SR, Maximum of RH, Average of RH, Minimum of RH, Maximum of AT, Average of AT, and Minimum of AT as seen in Figure 4. Figure 4 shows that during January 2013: The Average of Maximum $\mathrm{SR}=901 \pm 1 \mathrm{~W} / \mathrm{m}^{2}$, Average of SR $=470 \pm 1 \mathrm{~W} / \mathrm{m}^{2}$, The Average Accumulation of SR $=319984 \pm 1 \mathrm{~W} /$ $\mathrm{m}^{2}$, The Accumulation of SR $=9599519 \pm 1 \mathrm{~W} /$ $\mathrm{m}^{2}$. In the same way, the calculations for RH and AT were performed (see Figures 5 and 6). Figure 5 shows the calculations of RH for January 2013.

Figure 5 shows that: Average of the Maximums of RH $=61 \pm 3 \%$, Average of $\mathrm{RH}=48 \pm 3 \%$, Average of Minimums of RH $=31 \pm 3 \%$. From Figure 6, we found that: Average of Maximums of $\mathrm{AT}=28.8 \pm 0.6{ }^{\circ} \mathrm{C}$, Average of $\mathrm{AT}=23.2 \pm 0.6^{\circ} \mathrm{C}$, Average Minimums of AT $=19.1 \pm 0.6^{\circ} \mathrm{C}$. During January 2013, it was found that: The Maximums of SR=1282 $\pm 1 \mathrm{~W} / \mathrm{m}^{2}$ (In January 29), The Maximums of RH $=75 \pm 3 \%$ (In January 9, 30), The Maximums of AT $=32.3 \pm 0.6{ }^{\circ} \mathrm{C}$ (In January 3). The investigation was carried out in the same way for the rest of the months of the year 2013. The summary of all months is shown in Table 3. 


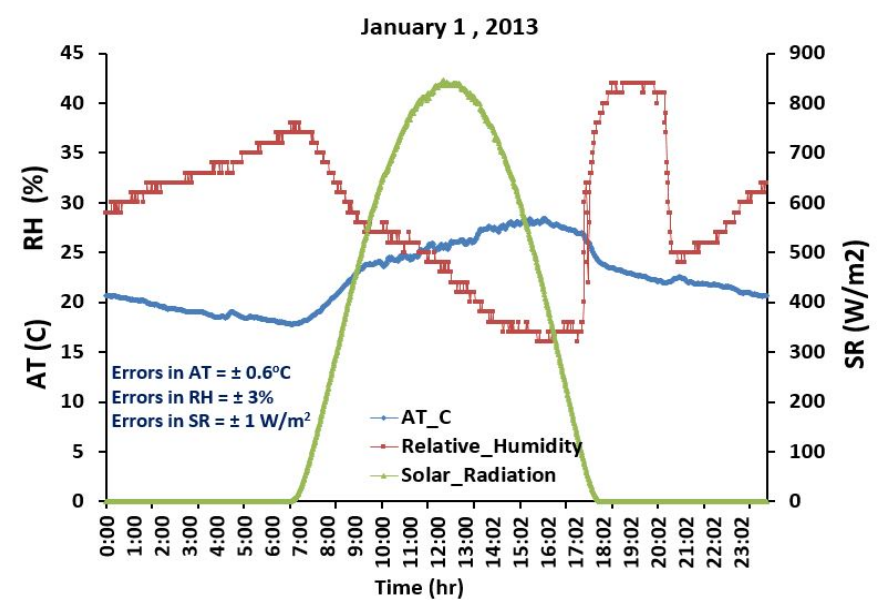

Figure 3: The collected data of SR, RH and AT

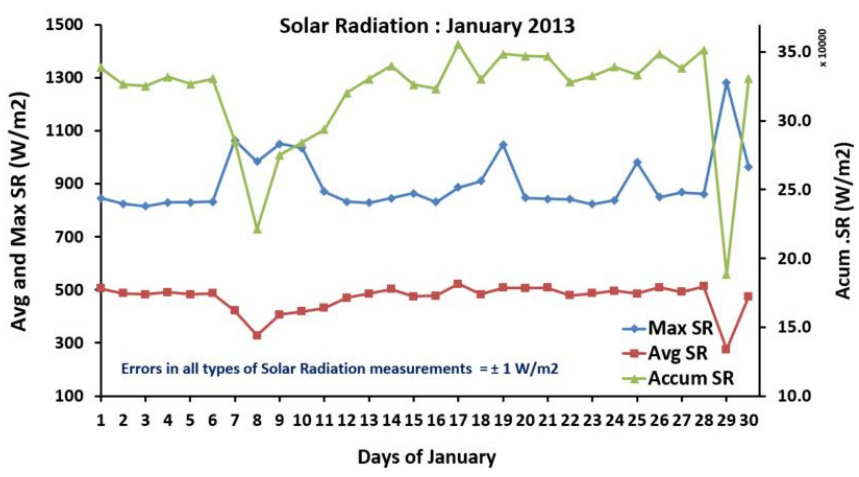

Figure 4: Solar irradiation for January 2013

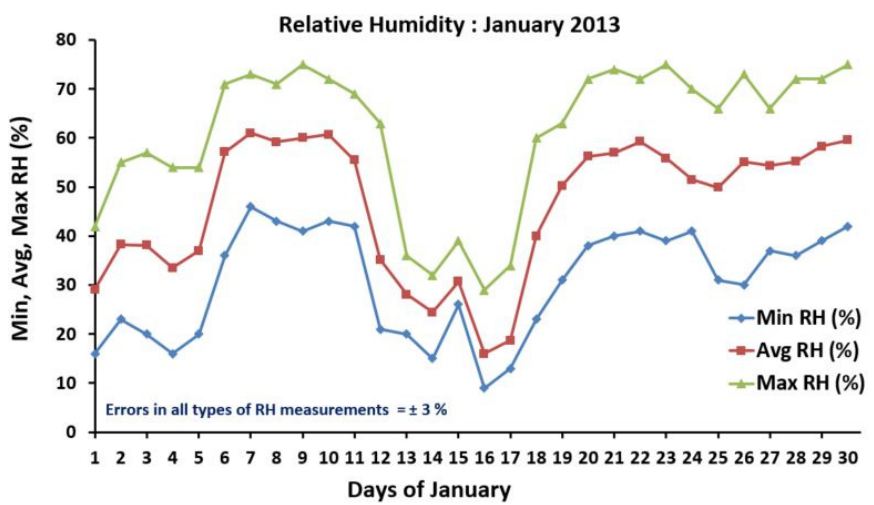

Figure 5: Relative humidity for January 2013

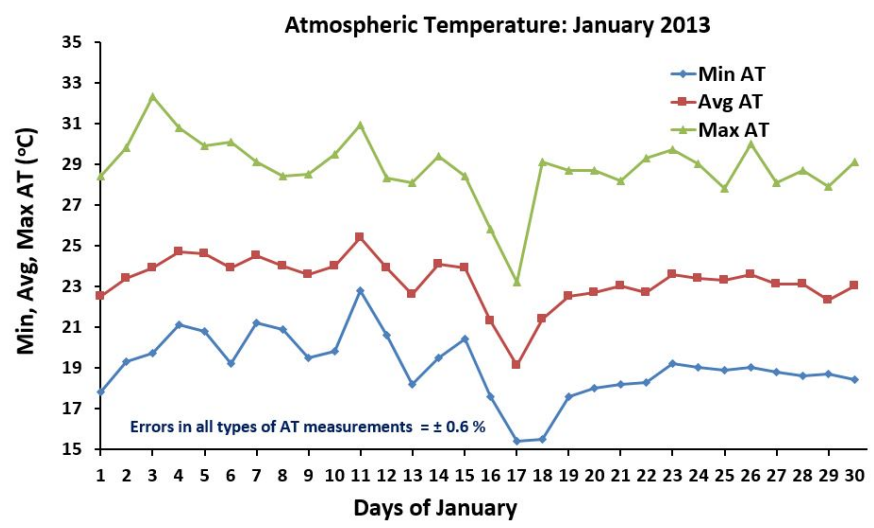

Figure 6: Atmospheric temperature for January 2013 
Table 4: The maximum SR, RH, and AT found in the year 2013 at Dhofar University

\begin{tabular}{|l|c|c|c|}
\hline \multicolumn{1}{|c|}{ Month } & $\begin{array}{c}\text { Max SR }\left( \pm 1 \mathrm{~W} / \mathrm{m}^{2}\right) \\
\text { (Day/s number) }\end{array}$ & $\begin{array}{c}\text { Max RH }( \pm 3 \%) \\
(\text { Day/s number) }\end{array}$ & $\begin{array}{c}\text { Max AT }\left( \pm 0.6^{\circ} \mathrm{C}\right) \\
(\text { Day/s number) }\end{array}$ \\
\hline January & $1282.00(29)$ & $75.00(9.30)$ & $32.30(3)$ \\
\hline February & $1249.00(12)$ & $88.00(3)$ & $32.20(15)$ \\
\hline March & $1360.00(26)$ & $88.00(26)$ & $36.40(8)$ \\
\hline April & $1362.00(5)$ & $90.00(3,4)$ & $38.80(2)$ \\
\hline May & $1280.00(7)$ & $87.00(31)$ & $31.80(19)$ \\
\hline June & $1149.00(24)$ & $94.00(29)$ & $29.5(9)$ \\
\hline July & $1027.85(13)$ & $95.6(1-11,15-31)$ & $28.9(21)$ \\
\hline August & $1034.22(15)$ & $94.00(20-30)$ & $34.50(20)$ \\
\hline September & $1062.20(18)$ & $88.20(4-8,20-25)$ & $37.75(15)$ \\
\hline October & $1144.79(5)$ & $95.00(10)$ & $36.70(7)$ \\
\hline November & $980.00(16)$ & $83.00(22)$ & $34.90(4)$ \\
\hline December & $1022.00(13)$ & $81.00(8)$ & $(10)$ \\
\hline
\end{tabular}

Table 3: Summary of the measured and calculated SR, RH and AT for all months of the year 2013

\begin{tabular}{|c|c|c|c|c|c|c|c|c|c|c|}
\hline Month & $\begin{array}{c}\text { Avg. } \\
\text { Max SR } \\
\left( \pm 1 \mathrm{~W} / \mathrm{m}^{2}\right)\end{array}$ & $\begin{array}{c}\text { Avg.SR } \\
\left( \pm 1 \mathrm{~W} / \mathrm{m}^{2}\right)\end{array}$ & $\begin{array}{c}\text { Avg. } \\
\text { Accum SR } \\
\left( \pm 1 \mathrm{~W} / \mathrm{m}^{2}\right) \\
\times 1000\end{array}$ & $\begin{array}{c}\text { Accum } \\
\left( \pm 1 W / m^{2}\right) \\
\times 10,000\end{array}$ & $\begin{array}{c}\text { Avg.Max } \\
\text { RH } \\
( \pm 3 \%)\end{array}$ & $\begin{array}{c}\text { Avg.RH } \\
( \pm 3 \%)\end{array}$ & $\begin{array}{c}\text { AvgMin } \\
\text { RH } \\
( \pm 3 \%)\end{array}$ & $\begin{array}{c}\text { AvgMax } \\
\text { AT } \\
\left( \pm 0.6^{\circ} \mathrm{C}\right)\end{array}$ & $\begin{array}{c}\text { Avg AT } \\
\left( \pm 0.6{ }^{\circ} \mathrm{C}\right)\end{array}$ & $\begin{array}{c}\text { AvgMin } \\
\text { AT } \\
\left( \pm 0.6^{\circ} \mathrm{C}\right)\end{array}$ \\
\hline January & 900.77 & 469.93 & 319.0 & 959 & 61.20 & 47.57 & 30.60 & 28.84 & 23.24 & 19.07 \\
\hline February & 991.57 & 542.95 & 331.0 & 1067 & 65.25 & 49.79 & 32.28 & 29.38 & 24.06 & 19.66 \\
\hline March & 1100.97 & 558.54 & 406.0 & 1258 & 72.03 & 50.57 & 31.06 & 32.24 & 26.82 & 22.35 \\
\hline April & 1111.68 & 540.97 & 422.0 & 1264 & 80.52 & 63.27 & 41.48 & 33.91 & 28.99 & 25.56 \\
\hline May & 1058.71 & 547.55 & 428.0 & 1327 & 81.65 & 66.09 & 44.27 & 36.00 & 30.93 & 27.40 \\
\hline June & 966.60 & 425.25 & 336.0 & 1010 & 87.13 & 75.62 & 56.60 & 33.89 & 29.39 & 26.95 \\
\hline July & 864.68 & 380.41 & 301.7 & 9039 & 97.40 & 86.4 & 77.60 & 28.90 & 26.35 & 23.80 \\
\hline August & 870.04 & 382.77 & 303.2 & 909 & 96.80 & 87.40 & 80.00 & 26.70 & 25.72 & 23.75 \\
\hline September & 893.58 & 393.13 & 311.5 & 934 & 94.25 & 84.34 & 65.20 & 29.50 & 26.15 & 22.80 \\
\hline October & 963.06 & 423.70 & 335.0 & 1006 & 87.45 & 74.80 & 46.56 & 31.00 & 26.80 & 22.60 \\
\hline November & 896.27 & 4489.98 & 336.0 & 1008 & 68.70 & 53.63 & 34.70 & 32.83 & 27.49 & 23.53 \\
\hline December & 831.77 & 481.99 & 325.0 & 1007 & 55.76 & 38.76 & 24.83 & 30.35 & 24.80 & 20.64 \\
\hline
\end{tabular}

It can see (from Table 3) that: 1. In SR calculations: April gave the maximum average SR, March gave the best average, May month gave the best average accumulative of SR, and May is the best accumulation of SR among all months of the year 2013. In RH calculations: July gave the average maximum of RH, December gave the average minimum of $\mathrm{RH}$, and August gave the best average value. In AT calculations: May gave the average maximum of AT, January gave the average minimum of AT, and May gave the highest value of the average of AT. Among all maximums in all months, we found that: the maximum SR found in April, the maximum RH found in July, and the maximum value of AT found in May. The accumulative SR for the whole year of 2013 is $222 \pm 1 \mathrm{MW} / \mathrm{m}^{2}$.

\section{CONCLUSIONS}

The AWS installed was composed of firstclass pyranometer and the RH/AT sensors. The measured values of the SR, RH, and AT are for the year 2013. The measured values of all parameters used to make several calculations such as average, accumulative, average maximums, average minimums, average among all data measured. It can be concluded that May is the best for collection of solar irradiation, while July is the worst one of collection solar irradiation because of the presence of thick layers of clouds in the sky during this month, which prevented some of the solar radiation from reaching the surface of the earth. This can be seen clearly in the average maximum $\mathrm{RH}$ values which are found in July $(97 \pm 3 \%)$. 
Generally, most of the year is very good for the collection of solar radiation at Dhofar University (Dhofar Region). This makes Dhofar University (Dhofar Region) an excellent place for the Photothermal and Photovoltaic applications.

\section{Acknowledgments}

The research leading to these results has received research project grant funding from The Research Council (TRC) of the Sultanate of Oman under research agreement number [ORG DU EI 10 016]. Therefore, we are thankful to the TRC for their continuous support.

\section{REFERENCES}

1. AlYahya, S. and M.A. Irfan. 2016. Analysis from the new solar radiation Atlas for Saudi Arabia. Solar Energy, 130: 116-127.

2. Ertekin, C. and Yaldiz. O., 1999. Estimation of monthly average daily global radiation on horizontal surface for Antalya (Turkey). Renewable Energy, 17(1): p. 95-102.

3. Gairaa, K. and S. Benkaciali,. 2011. Analysis of solar radiation measurements at Ghardaïa area, south Algeria. Energy Procedia, 6: 122-129.

4. Jimenez. V.A., Barrionuevo. A., Will. A., Rodríguez. S. 2016. Neural Network for Estimating Daily Global Solar Radiation Using Temperature, Humidity and Pressure as Unique Climatic Input Variables. Smart Grid and Renewable Energy, 7(03): 94-103.
5. Lee, K., Yoo. H., and Levermore., G.J., 2013. Quality control and estimation hourly solar irradiation on inclined surfaces in South Korea. Renewable energy, 57: 190-199.

6. López, G., M.A. Rubio, and F.J. Batlles, 2000. Estimation of hourly direct normal from measured global solar irradiance in Spain. Renewable Energy, 21(2): 175-186.

7. Loutfi, H., Bernatchou. A., Raoui. Y., Tadili. R, 2017. Learning processes to predict the hourly global, direct, and diffuse solar irradiance from daily global radiation with artificial neural networks. International Journal of Photoenergy, doi. org/10.1155/2017/4025283

8. Matsumoto. Y., Valdés. M., Urbano. J. A., Kobayashi. T., López. G., Peña. R. 2014. Global solar irradiation in north Mexico city and some comparisons with the south. Energy Procedia, 57: 1179-1188.

9. Paulescu. M., Paulescu. E., Gravila. P., Badescu. V. 2012. Weather modeling and forecasting of PV systems operation. Springer, Berlin Heidelberg New York.

10. Pérez. B. A., Bilbao. J., De Miguel. A., Roman. R. 2014. Analysis of solar direct irradiance in Spain. Energy procedia, 57: 1070-1076.

11. Scharmer. K., Greif. J., 2000. The European Solar Radiation Atlas. Les Presses de 1'École des Mines: Paris.

12. Sabziparver A., Shetaee H. 2007. Estimation of global solar radiation in arid and semi-arid climates of East and West Iran. Energy, 32: 649-655.

13. Wazwaza, A., \& Salmi. J., 2010. Solar Net Collective Flux and Conversion Efficiency of the NickelPigmented Aluminium Oxide Selective Absorber Prepared by Alternate and Reverse Periodic Technique in Different Prototype Volumes. JJMIE, 4(1). 